TERRORISM AND THE LAW

\title{
Historical Contexts, Contemporary Dilemmas, and the End(s) of Democracy
}

\author{
Elizabeth Chadwick*
}

ABSTRACT: Recent proposals by the G7 (and Russia) to clamp down on "terrorists" and "terrorism" do not define that which is prohibited. Instead, a threat is communicated which in turn allows, among other things, greater attention to be paid officially to "Camouflage" charities and "terrorist" use of the Internet. Nevertheless, it is somewhat of a truism to note that terrorist violence is ultimately defined or characterized, for purposes of legal prohibition, within a highly politicized atmosphere. Starting with a short summary of "anti-terrorist" codification efforts made this century, this article examines some of the "security interests" cited by governments today in their respective struggles against "terrorism." More specifically, it is argued that individual perceptions of personal and societal threat are heightened unnecessarily not only by a constant stream of governmental "anti-terrorist" rhetoric, but further, by an awareness of official and unofficial methods of "antiterrorist" surveillance, and the use to which the information so obtained can be put. 


\section{Introduction}

On 26 June 1996, the G7, meeting in Lyon, approved a call from United States President Bill Clinton for a new international alliance to fight terrorist attacks. In the words of President Clinton, terrorism is

(T) he greatest security challenge of the twenty-first century. .... We cannot have economic security in a global economy unless we can stand against those forces of terrorism. The U.S. will lead the way and we expect our allies to walk with us hand in hand.l

Prompted in large part by a spate of recent terrorist attacks, the G7 proceeded to condemn world terrorism "in all its manifestations regardless of its perpetrators or motives." It was agreed further that "terrorism is a heinous crime and there must be no excuse or exception in bringing its perpetrators to justice." All countries were invited to join their efforts "to thwart the activities of terrorists and their supporters."2

At a follow-up special ministerial meeting on $30 \mathrm{July}$, in Paris, two main themes were pursued: transport security and the threat of bombings. ${ }^{3}$ specific measures agreed to by sixteen G7 foreign and security ministers, and Russia, included the easing of extradition arrangements, a clampdown on terrorist use of the Internet and "camouflage" charities, and the establishent of "a directory of counterterrorist skills" in order to combat different types of terrorism.4 U.S. proposals to impose isolating economic 
and other sanctions against states alleged to sponsor terrorism received a lukewarm response, as being too simplistic in view of radical changes in the nature of terrorism in recent years. 5

As can be seen from these statements, no effort is made to define that which is prohibited. This is perhaps logical in that there is to date no generally accepted definition of terrorism. On the other hand, acts of terrorism may be characterized by the fear they spread. The fear thus generated is then utilized to coerce changes in policy or behavior, thereby short-circuiting political processes which might otherwise produce the same result. If however an act of terrorism is simply "a heinous crime", much of the modern rhetoric surrounding efforts to define terrorism as a separable phenomenon appears insignificant. 6 Thus, what is communicated in these G7 statements is the existence of a danger to world security which must be countered through mutual co-operation.?

In view of this absence of definition, it is the purpose of this article to explore the outlawing of "terrorist" acts of political violence within the context of various of the "security interests" alluded to in the G7 statements noted above. 8 The structure of this discussion is as follows. First, a short general background is given of the origin and development of what today is referred to as terrorism. Efforts made this century to define terrorism, and to achieve international co-operation in the legal prohibition and criminalization of non-state terrorist acts, are then outlined briefly. The 
contemporary environment in which anti-terrorist laws are increasingly being enacted is the focal point of inquiry, and it is argued in particular that democratic governments heighten perceptions of threat, to national security for example, to justify the use of such "anti-terrorist" devices as official and unofficial methods of surveillance, and Internet monitoring. In turn, this must result in an increase in arbitrary constraints on individual private behavior.

\section{Terrorism: origins and Definitions}

\section{(a) The Origins of a Word}

The word "terrorism" derives from the era of the French Revolution and the Jacobin Dictatorship, during which a state-directed policy of inflicting terror was practised to obtain political and social control. As the Revolution was exported to the rest of Europe, the word gained international currency in both domestic and international, individual and state, contexts. In turn, popular resistance to the Napoleonic invasion of the Spanish Peninsula led to a new concept of modern warfare - the "guerrilla," which derives from the Spanish word "guerra" and translates as "little war."9 As a weapon of politics and warfare, however, the use of group terrorism can be traced easily to more ancient times.

For example, by the twelfth and thirteenth centuries, a group known as the "Assassins" had appeared. The term "assassin" derives from Arabic, and translates as "hashisheaters." The group were sectarian Moslem fanatics, who, 
acting under the influence of drugs, used murder as a political weapon. The solitary terrorist actor, on the other hand, appeared with the rise of the nation-state. 10 Friedlander notes that the centralization of political structures during the formative period of the national state led to "a philosophic justification for individualized attacks against ... the visible symbol of the new statism" (usually the monarch), as well as against abuses of public power, generally.11

By the mid-nineteenth century, many extradition treaties exempted fugitives accused of "political offenses" or "crimes of a political character" from extradition.12 The development of the political offense exception originated during the French Revolution when France offered sanctuary to revolutionary dissidents from other parts of Europe. 13 The decades following the Congress of Vienna saw the growth of a European-wide revolutionary tradition. Most Western European governments were encouraged to modify their stance on the grant of asylum to alleged perpetrators of political crimes. 14

Revolutionary terrorism achieved its classic form in nineteenth century Russia. While many commentators insist that Mikhail Bakunin, founder of radical anarchism, should be considered the archetype of revolutionary terrorism, the anarchist movement was by no means the only terror organization which endeavored to transform Russian society and government by assassination politics prior to World War I. 15 Revolutionary terrorism was also utilized as an unofficial instrument of national foreign policy elsewhere 
in Europe. For example, the Union or Death Society, popularly known as the Black Hand, was a secret Serbian revolutionary organization whose primary aim was to bring about a Greater Serbia. Its tactics included transnational acts of assassination, and the Austrian Archduke Franz Ferdinand was assassinated in June 1914 by a terrorist trained by the Black Hand. 16

Only the conservative regimes of Prussia, Russia, Austria, and Naples continued during this time to advocate that ideologically similar nations should use their extradition laws to help suppress each other's revolutionaries. 17 On the other hand, specific protections for Heads of State also began to emerge by the midnineteenth century. Related attempts early this century to organize an international response to terrorism were more germane to immigration issues. These included a protocol concerning measures to be taken against the anarchist movement, signed on behalf of nine states at St. Petersburg, I - 14 March 1904, an administrative convention for the exchange of information concerning individuals dangerous to society, signed at Buenos Aires, 20 October 1905, and an agreement concerning mutual defense against undesirable foreigners, signed at Quito, 10 August 1935.18

\section{(b) Early Efforts at Definition: the 1937 Terrorist Convention}

A legal commentator in 1933 indicated that it is more desirable for the world community to proscribe and punish certain offenses than to attempt any unification of 
criminal law. 19 By this point in time, several bipartite agreements already related to the suppression of terrorism, and many extradition treaties contained clauses excluding attempts against Heads of State from the list of political offenses. 20

On the other hand, and with particular regard to the political offense exception, it was also noted in 1933 that "( $t$ )he definition of this category tends to become broader in an era of exacerbated nationalism like the present."21 This observation was made within the context of achieving a sufficient level of international co-operation to ensure that domestic legislation would permit states to exercise jurisdiction over criminal acts wherever they might be committed. Nevertheless, there remained two major obstacles: first, divergences of law and procedure between legal systems are difficult to reconcile for this purpose; secondly, the full exchange of information in a "logical and just division among the various countries of their sovereign jurisdiction to punish for crime"22 is not only difficult to achieve, but can be expensive.

The assassinations of King Alexander I of Yugoslavia and the French Minister for Foreign Affairs, appearing together at Marseilles on 9 October 1934, brought matters to a head. The extradition of persons accused of the assassinations was refused by Italy on the grounds that the offense was political. The Council of the League of Nations then received a memorandum from the French Government regarding "international measures" for the suppression of political crimes. The Council set up a 
Committee of Experts to draft a Convention "to assure the repression of conspiracies or crimes committed with a political purpose."23

On 16 November 1937, the League of Nations opened the Terrorism Convention for signature. 24 It was promptly signed by the representatives of twenty states. Article l(1) reaffirms the duty of "every state to refrain from any act designed to encourage terrorist activities directed against another state." Article l(2) defines "acts of terrorism" as "criminal acts directed against a state." Such acts must be "intended or calculated to create a state of terror in the minds of particular persons, or a group of persons or the general public."25 Article 2 specifies the acts which should constitute terrorist criminal offenses, in order that each High Contracting Party could implement domestic penal legislation. These Article 2 acts, in synopsis, are as follows:

1. Wilfully causing death, grievous bodily harm or loss of liberty to Heads of State, their equivalents, their spouses, or other persons charged with public functions;

2. Wilful destruction of public property;

3. Wilfully endangering the lives of members of the public;

4. Wilfully attempting the above offenses;

5. Manufacturing, obtaining, possessing, or supplying arms, etc., for the commission of the above offenses. 
Article 2 indicates that the prosecution and punishment of violent political crimes turn on domestic interpretations of the nature of the violent act, as follows:

... (I)f they (terrorist acts) are directed against another High Contracting Party and if they constitute acts of terrorism within the meaning of Article 1.

Article 19 provides:

The present Convention does not affect the principle that, provided the offender is not allowed to escape punishment owing to an omission in the criminal law, the characterization of the various offences dealt with in the present Convention, the imposition of sentences, the methods of prosecution and trial, and the rules as to mitigating circumstances, pardon and amnesty are determined in each country by the provisions of domestic law.

These provisions in particular are of interest because their precise wording allows a prosecuting state a wide scope for discretion in interpretation.26 The danger is that a state which refuses to interpret an offense as criminal for purposes of prosecution, or to extradite the alleged offender for reasons of sovereignty or suspected judicial injustice in the requesting state, for example, may find itself accused of intervention in the internal 
affairs of the requesting state, and embroil itself in a situation of interstate friction.

State and regional traditions of asylum, and strong national sympathies may interject political considerations into the analysis, ensuring that the political offense exception - or other interpretational device - remains applicable. A grant of asylum may also obviate the risk of prosecution for what can be interpreted as a political offense. Further, any refusal to extradite, where arquably there is a clear duty to do so, still leaves the custodial state with the duty to prosecute 27 , although this may be conducted sympathetically.

Thus, the picture which emerges in 1937, and which endures in anti-terrorist, refugee, extradition, etc., codifications alike, is one of a community of states which is reluctant to cede, individually, its powers of sovereign authoritative interpretation for purposes of co-ordinating characterizations of the criminality of particular acts in domestic law. As of 1 January 1941, only India had ratified the Terrorism Convention, and it never entered into force.

\section{Contemporary Approaches to Terrorism}

\section{(a) Codification Efforts since 1945}

Anti-terrorist provisions are reflected in post-1945 human rights codifications, in measures to protect civil aviation, and in broader declarations such as United Nations General Assembly Resolutions, and the Helsinki accords. 28 Benchmarks utilized to identify terrorist acts 
within these many contexts include acts such as the wanton targeting of innocent civilians or their property for motives unrelated to the damage inflicted. 29

Other commentators employ the language of warfare, and an obvious characteristic of the post-1945 era has been the attempt to regulate tactics of terror-violence deployed by liberation fighters utilizing "direct action."30 However, while the use of force in an armed conflict strictly speaking is already regulated by international humanitarian law, an armed conflict must first be recognized, and it is largely for this reason that much terrorism is viewed as perpetrated during so-called "peacetime."31 The negative effect of such a view is the specter of the political offense exception, which by its nature is afforded on a country-specific basis, and threatens international efforts to co-ordinate measures against the use of terrorism.

There are essentially two predictors of the success of mutual co-operation in terrorist matters: legal tradition, and political alliance. In this respect, the European Convention on the Suppression of Terrorism of 1977, signed under the auspices of the Council of Europe ${ }^{32}$, and the U.S.-U.K. Supplementary Extradition Treaty of 198533, are of interest. Both codifications were drafted with the armed situation occurring in Northern Ireland since the late 1960s in mind. While neither agreement attempts to define terrorism, and each is silent regarding the issue of armed conflicts for self-determination, both agreements list specific offenses to be excluded from the political 
offense exception for purposes of extradition, and the two lists are similar. 34

The main difference between the two is that the European Convention is not an extradition treaty, and thus is viewed as merely providing a basis for extradition. Otherwise, the scope afforded for discretion in determining the non/-extradition of an alleged terrorist offender differs. For example, Article 3(a) of the U.S.-U.K. Extradition Treaty allows extradition to be denied if it can be shown the individual would suffer religious, political or racial discrimination upon return. However, as the two countries are self-styled "stable democracies"35, the accused carries a heavy burden of proof and he still, no doubt, will be prosecuted. Article 5 of the European Convention on the other hand utilizes the formula of "race, religion, nationality or political opinion." Further, Article 13 allows a Contracting State to declare that it reserves the right to refuse extradition for any of the listed terrorist offenses it considers a "political offence, an offence connected with a political offence or an offence inspired by political motives." Obviously, states which share the same or similar juridical sources may find mutual co-operation more attainable. Similarly, offense-specific agreements have been more favorably received 36 , generally speaking, than global anti-terrorist codifications. Thus, the prospects for success of the International Law Commission's current project under United Nations auspices to develop a global 
Draft Code of Crimes against the Peace and Security of Mankind is of interest.

The Draft Code is designed to deal, inter alia, with war crimes, and genocide through a treaty format. The inclusion of crimes of international terrorism remains controversial, although the special rapporteur has proposed such crimes be retained. This was a project commenced after World War II which stalled during the Cold War. It has recently been revived by the United Nations but doubts exist as to its future acceptability on any universalized basis. 37

\section{(b) The Dilemmas of Codification}

A preliminary point regarding such global efforts to criminalize acts of terrorism as developed recently by the G7 and Russia is that the effective deterrence of political violence depends on individual domestic state action and interpretation of specifically defined acts. In turn, achieving such a high level of mutual co-operation in terrorist (or criminal) matters is made problematic by world disunity in other areas, such as human rights. For example, an Islamic faction may "terrorize" women who wish to work outside the home and to vote, or who do not wish to wear the veil. An ethnic war may erupt in which torture or murder against innocent civilians is practised as a matter of course.

A perception that states can only control the incidence of terrorism, as well as rises in ordinary crime, through repressive internal policies works in aid of those 
governments which criminalize modes of individual behavior posing a threat to their political legitimacy. 38 Moreover, variations between states in their domestic definition of "terrorism" constitutes evidence that the labeling process is a highly politicized one. As state prosecutors, generally-speaking, need only treat a particular terrorist allegation as a serious criminal matter, whether, or how, the state proceeds remains open. In turn, the domestic law in force, or the interpretation of it by the relevant authorities, may prove ineffective when the time arrives to apprehend or prosecute "terrorists."

It will be apparent by this point in the discussion that the many efforts to define and control world terrorism thus depend to a certain extent on the context in which it appears desirable to criminalize a proscribed act. Friedlander 39 argues however that

(E)ven though there is no acceptable legal definition as of this date, there need not be if one deals with terrorism as a criminal act. Whatever the means and however employed, acts of terror-violence are common crimes in every civilized society on this earth. Therefore, an exact legal definition is not necessary, if one merely deals with the elements of the actus reus in question: murder, serious bodily harm, reckless endangerment, intentional infliction of severe mental distress. 
Viewed in this light, defining precisely for political or legal purposes what is (or is not) an act of terrorism loses much of its significance. ${ }^{40}$ Put simply, if the inherent political nature of terrorism is ignored, terrorist acts can be identified more easily for purposes of prosecution. The sheer variety of motives, actors, arenas of activity, and target audiences, further serve to cloud any attempt to distinguish terrorist activity from pure criminal acts, e.g., for personal gain.41 It can also be argued plausibly that defining "terrorism" through the lens of its allegedly "inherent" political nature is practicably impossible. A definition which requires evidence of an intent to spread fear (for whatever purpose) by means of acts of violence is completely different, and much more problematic, than a requirement of proof of an intent to throw a bomb, for instance.

On the other hand, a simplistic approach to the identification of terrorist offenses implies that each such offense must be specifically listed, which in fact has been the preferred formula of many anti-terrorist codifications. The latter formula is also problematic for two reasons. The first has already been discussed: states retain a degree of discretion when deciding whether to extradite or prosecute particular violent offenders, and terrorist acts which have mixed "criminal" and "political" elements may elicit a sympathetic response from interpreting authorities, and lead to a grant of asylum. Secondly, a government may exempt itself from prosecution for acts of terrorism perpetrated by its agents 
in the course of official duty ${ }^{42}$, which official acts may in turn provoke unlawful "terrorist" activity. Thus, while mutuality of state interest in the suppression of international terrorism is necessary before assistance and co-operation arrangements can be made workable, the scope afforded to state discretion undercuts this mutuality, particularly when political crimes are in issue. 43

\section{Terrorism and the Interests of Security}

\section{(a) Situating 'Terrorism'}

International anti-terrorist co-operation is achieved in both bi-lateral and multi-lateral formats which require governments individually to implement extradition and/or anti-terrorist laws reflecting levels of dual criminality for these purposes. 44 Nevertheless, a politicized process of characterization and identification, which exhibits both the dictates of domestic culture and the power relations within it, are what lie at the heart of much of the effectiveness of state penal law in general, and antiterrorist law harmonization in particular.

As noted above, abuses of public power during the rise of the nation-state led to a modern philosophic justification for acts of political violence. During the French Revolution, revolutionary terrorists violently seized and maintained social and political control. During the late nineteenth and early twentieth centuries, increased protections afforded to Heads of State, the regulation of the movements of "undesirable foreigners," and the relative acceptance by states of the political 
offense exception to prosecution or extradition indicate that broad limits of "permissible revolutionary activity"45 existed.

In regard to the latter point, it is of central interest to this section that Western governments in particular have struggled for centuries to contain the incidence of "terrorism" within strategic, and utilitarian, parameters. More recently, the Cold War between U.S. and U.S.S.R. strategic interests ensured sufficient non-cooperation between them in international matters to permit correspondingly competing analyses of the causes of the phenomenon of international terrorism. 46 Today, and as reflected in the G7 statements noted at the beginning of this discussion, a largely free market post-Cold war environment still finds itself presented with the threat of terrorism, the difference now being that terrorism is referred to as "the greatest security challenge of the twenty-first century"47, and that "security" appears collective. In other words, world governments appear prepared to "advocate ... that ideologically similar nations should use their laws ... to help suppress each other's revolutionaries" 48 once again.

This new shift in perspective may be due to the fact that terrorist violence is still characterized as having been crucial historically to centralizations of, and shifts in, interstate power relations. For example, revolutionary terrorism and terrorist anarchism are depicted as rooted, for purposes of rationale, in the oppression of the working class particularly during the nineteenth century era of 
Western industrialization. 49 After 1945, much of the literature on terrorism shifted to analyses of the sources of funding of Third World liberation armies (or "terrorist bands"), as such groups struggled against colonial domination and capitalist imperialism.50

Today, interpretations of the use of political violence may be redefined once again, particularly in relation to modern issue-structures such as the international politics of domestic state poverty ${ }^{51}$, or the globalization of sophisticated communications systems like the Internet.52 However, proposed G7 and Russian cooperation in the specific form of measures such as a clampdown on terrorist use of the Internet and "camouflage" charities, and the establishment of "a directory of counter-terrorist skills"53, risks increasing levels of tolerance to violence by governments, terrorists, and victimized populations alike, and it is this latter point which is now developed.

\section{(b) Terrorism, Labeling, and Communication}

Each violent act perpetrated by gun-toting, bomb-throwing "terrorists" such as Carlos the Jackal, the members of the Beider-Meinhof gang, the Abu Nidal Organization ${ }^{54}$, the I.R.A.55, the P.L.0.56, the rebel groups fighting until recently for Chechen independence 57 , involves the destruction of life or property without the sanction of the law. In other words, each act occurs beyond the penumbra of the state monopoly on the use of force. 58 Thus, each of the enumerated acts politically may be termed "terrorism." 
As previously indicated, state identification of "terrorist" groups or individuals, and the legal qualifications attributed to their activities, depends in the final analysis on a high level of political control over the labeling process, as well as the effective communication of this process. Thus, effective communication through language use is very much at the heart of both terrorist and anti-terrorist activities. Equally, it is possible that particular "terrorist" acts are not criminalized (or prosecuted) by some governments for political reasons. The U.S. defines terrorism, for purposes of civil remedies, for instance, to exclude damage caused by war, by the U.S., its officers or those of foreign states acting within their official capacities. Instead, "terrorism" is an activity involving violent acts which: (1) violate U.S. criminal laws or the law of any state; (2) appear to be intended to intimidate or coerce a civilian population, to influence the policy of a government, or to affect the conduct of a government by assassination or kidnapping; and (3) occur primarily outside the territorial jurisdiction of the U.S..59 Not surprisingly, this definition makes no distinction between acts of liberation armies, violent acts perpetrated for personal gain, or violence related to psychological causes, nor does this definition make justiciable in the indicated manner acts which might otherwise be viewed as acts of terrorism where they are performed by U.S. or foreign officials in their official capacities.60 Further, by viewing members of terrorist organizations as individual 
juridical subjects, who each carry individual penal responsibility, formal egalitarian political frameworks may be maintained. This definition also appears to allow the exercise of extraterritorial jurisdiction.

Whether or not this particular U.S. definition encapsulates and assumes the immunity afforded by the act of state doctrine - which allows in certain circumstances a basic differentiation in conduct between the behavioral discipline and standards required of ordinary U.S. citizens and that of state and federal officials, or their representatives - the politically dominant class which can exempt itself from prosecution in this manner illustrates the double standard involved in the official power to identify "terrorists." Put more plainly, and by way of example, the special protection afforded to Heads of State and other state officials by many terrorist codifications means that "the creation of a specially protected class of governmental officals has had the effect of legitimizing all regimes under the protective cover of anti-terrorist statutes." 61

Any international harmonization of anti-terrorist criminal standards by the world community is thus efficacious for purposes of normalizing the concepts with which participating states can identify and take action regarding individual "terrorists." Moreover, this point supports the notion that states sharing the same or similar juridical sources may find mutual co-operation more attainable, and further implies a second level of collectivist duality: "terrorist" individuals can be 
approached more systematically through contexts of (1) "binary division and branding" (good/evil, right/wrong), and of (2) "coercive assignment, of differential distribution" (how the terrorist is to be characterized, etc.). .62

Nevertheless, states can also deprive dissenters of their voice in this normalized and systematic way ${ }^{63}$, particularly as acts of terrorism are capable of interpretation in language other than that employed by a government to describe measures necessary for the maintenance of law and order. ${ }^{64}$ While it is not the purpose of this article to justify, or apologize for the perpetrators of political violence, it has unfortunately become something of a truism that generalized official rhetoric surrounding terrorism and extradition can obscure equally viable arguments regarding "rights" entitlements.65 In turn, the effective undermining of the potential legitimacy of group-based claims through official techniques which isolate or segregate the voices of dissent can exacerbate the incidence of violence.

Thus, an individually-focused legal and political process which erases group membership serves to insulate a terrorist-targeted state from accusations of rights deprivations. "Terrorist" agitators may counter perceived government repression of this kind with violent acts followed by justificatory verbal signals.66 Moreover, the use of terrorist tactics may also reflect a group desire to disseminate a lack of tolerance or impatience with constitutional processes, a fundamental disagreement with 
governmental goal structures, or a desire to create for international consumption the appearance both of a viable political relationship with a target government, and a competent, legal existence.

\section{(c) Governments and Force}

Domestic legal norms are used to regulate the use of violence in a society, and official force is the tool of last resort, preferably, with which governments maintain public order. Devlin67 notes for example that violence is officially authorized by the legislative and executive branches of government, is sanctioned by the judiciary, and is perpetrated through policy, the use of the military, etc.. Official force is efficient in terms of time and available resources, and when used, it may be difficult to mount a legal challenge to it.

Violence is thus endemic to any conception of modern law68, and the legal qualification assigned to an act against which official force is used determines subsequent assessment of responsibility and liability. Responsibility for a terrorist act is determined by the legal qualification attributed to the act by a threatened government, or in some cases a third state. Moreover, assessments of responsibility for damage to life or property interests resulting from terrorism (or crime) have political consequences. The adverse political consequences which flow from terrorist damage operate therefore in inverse proportion to the trust which a government strives 
to engender in its ability to maintain law, order, and economic stability.

Such "trust" in turn is a function of a government's ability to normalize modes of individual, disciplined conduct - in other words, to reduce the risk of "criminals" and "terrorists" disrupting civil life. Giddens in particular notes that "trust' operates in environments of risk, in which varying levels of security, or protection against dangers, can be achieved."69 The trust placed in an airline pilot to arrive safely at the desired destination is illustrative of this point, implying further that trust results from perceptions of reliability within the context of contingent outcomes. ${ }^{70}$

Moreover, trust in the operation of an individual state public order system, as expressed through a decision to invest foreign capital for example, provides some evidence of a belief in the correctness (or at least, effectiveness) of the principles which underlie the domestic legal norms used to regulate societal levels of violence generally, and, in particular, the efficacy of governmental uses of force in the event of civil disorder. Such foreign investment "trust" can be the result of government assurances to this effect, as well as of prior records of reliability.

Nevertheless, a state which can only enforce societal discipline (and thus engender "trust") by enacting overlyrepressive laws in areas of international intercourse such as immigration, asylum, terrorism, and ordinary crime risks the perception that it cannot otherwise protect citizens 
and business interests. For instance, the ready use of military or police force by states to control domestic life and political activity may transform missions to restore public order into low-intensity warfare71, and "routinize" emergency situations, generally. ${ }^{72}$ Perhaps more importantly for purposes of the present discussion, any corresponding refusal to hold officials or soldiers responsible or accountable for atrocities committed during "peacetime" public order maintenance missions" 73 further exacerbates the inter-state lack of consensus regarding a satisfactory approach to international terrorism.

It should by now be apparent that domestic state political processes and interstate relations alike may be hindered by a heavy-handed maintenance of public order. Inter-penetrations between the many local and global considerations implicated in trade or human rights issues further support the importance of projecting an image of reliability and trustworthiness in the stability of the internal order of each state concerned.

Western governments in particular have traditions of democratic legitimacy to maintain, but "the rapidity of change in conditions of modernity"74, amongst other factors, has meant that resources for these purposes are concentrated increasingly on more subtle mechanisms. Control-through-surveillance, rather than resort being made to the more openly-repressive tactics of military or totalitarian regimes, forms the focal point of the next section. 
(d) Trust, Surveillance, and Violence

Turning once again to the purely domestic situation from which the "trust" just discussed arises, it can be argued that control over individual activity produces the requisite institutional discipline to attract investment. By way of corollary, such control carries the additional benefit of potentially deterring crime. As stated by President Clinton, "(w) e cannot have economic security in a global economy unless we can stand against those forces of terrorism."75 In other words, just as military discipline leads to reliability in arms, employable skills require a "web of workplace discipline"76, and from discipline, surveillance over human activity flows.

In similar vein, Giddens adds:

... (A)dministrative concentration depends ... upon the development of 'surveillance' capacities, ... . Surveillance refers to the supervision of the activities of subject populations in the political sphere - although its importance as a basis of administrative power is by no means confined to that sphere. Supervision may be direct (as in ... prisons, schools, or open workplaces), but more characteristically it is indirect and based upon the control of information. ${ }^{77}$

... (T)here are close substantive connections between the surveillance operations of nation-states and the altered nature of military power in the modern period. The successful monopoly of the means of violence on 
the part of the modern state rests upon the secular maintenance of new codes of criminal law, plus the supervisory control of 'deviance.' 78

Therefore, it can be argued plausibly that increased powers of surveillance activity on the part of, and within, industrialized states translate easily not only into greater levels of social control over individual life, but further, into facilitating the criminalization of modes of behavior which may constitute a danger to the "trust" ruling elites need to attract. Reducing a "terrorist" act which affects economic stability to a strict liability crime, in which only the actus reus matters, is merely a step away. 79

Moreover, while it is not difficult to view terrorism as a separably identifiable phenomenon on the basis of its "inherent" political nature, the widespread diffusion by government and media of the notions of fear and apprehension through many aspects of popular life and culture heightens perceptions of generalized risk, and creates additional conceptual space in which governments can interfere in daily life. For example, the word "terrorism" is being utilized emotively, rather than intellectually, to describe the content of film, the mechanization of modern banking, the links between information technology and child pornography, and societal relations in general. 80 The negative economic effects of conservatism/neoliberalism are focused upon by some 
commentators as producing the conditions in which acts of terrorism may arise and thrive. 81

Assuming that "trust" implies an absence, or reduction, of the elements of risk within the context of contingent outcomes 82 , what becomes central to increasing the levels of public tolerance to official (and unofficial) violence is trust in governmental "peacekeeping," itself sourced in an image of reliability, whether of government leaders, operations systems, and/or internal means to maintain order, and thus counter threats.

While this latter point illustrates the efficacy for post-Cold War governments of employing collectively the rhetoric of danger and security, another concern involves the parallel explosion in global communications. Terrorist use of mechanisms such as the Internet is the subject of recent G7 action. Nevertheless, a more generalized approach to access to information must also be considered for reasons which in the final analysis are exacerbated by politicized definitions of terrorism.

For example, global communications facilitate multinational corporate interests as easily as they do the interests of international terrorists and criminals, and Sloan in particular expresses concern that "the developed democratic orders" 83 are the most sophisticated consumers and manipulators of computer and informational technology. In exploring the organization and activities of the private security firms which service corporate security and surveillance capabilities, sloan highlights the fact that governments may be pursuaded to factor-in the scope of 
these private facilities when calculating the state resources required to maintain law and order.

The capacity for individual governments to gauge the extent and availability of all the security operations and resources available to them, in order to subsequently interpret what is and what is not (or will not be) considered criminal and/or terrorist activity, is then in issue.84 For example, should a government draft legislation which does not extend similar forms of public scrutiny and control over the activities of private security interests as it does over its own law enforcement and intelligence communities, the private ability to intrude into, control, and threaten the social, political, and private lives of individual citizens - a form of psychological terrorism - can go unchecked. Further, whether the power exists to extend such legislation extraterritorially to control the security activities of a multinational operating in different states is unclear.

Conversely, governments which do not choose to overregulate the security activities of corporations, or of private security firms, can themselves rely on these private facilities to avoid public accountability, which in turn constitutes a further risk to traditional notions of individual liberty. 85 The ease with which private interests can conduct surveillance activities, and threaten the personal security zones of individuals, and the ease with which the information gathered can be acquired and manipulated by an employer or government agent alike, means that any resulting personal intimidation can be made highly 
individualized.86 In turn, the connectivity of experience between "targeted" individuals is broken. 87

The multinational corporation (or other interest group) which can utilize its information technology to exert coercive control over citizens in different states through its access to and manipulation of personal data may also be of great benefit to a variety of governments in their efforts collectively to coerce modes of domestic order and individual behavior. Moreover, client governments can better obviate the risk of communicating an impression that physical force is required domestically to fulfill the security obligations of trade and other interests.

The global availability of surveillance capability carries enormous implications when the time arrives for legislators and intergovernmental experts to co-operate on definitions of "terrorism," and to identify "terrorists." In other words, while the economically "undisciplined," criminalized terrorist may be guilty of throwing bombs literally - for political purposes, his brother, the surveillance expert, may also represent a threat to life or property by his ability to manipulate and distort personal information. The former receives a prison sentence. The latter, because he works in furtherance of some system of superior power 88 , receives police protection, or, just a lack of legislative control.

\section{v. Conclusion}


U.S. proposals to impose sanctions on terrorist-sponsoring states were sidestepped by the G7 in late July 1996 largely on the basis that the nature of terrorism has changed radically in recent years. 89 For example, while "terrorist" tactics have to a certain extent been assessed traditionally against forms of conventional warfare 90 , it has now become argueable that "the boundary between terrorism and legitimate resistance" 91 encompasses perspectives which extend far beyond the more conventional confines of physical force and murderous violence. Thus, the security considerations noted early in this discussion 92 cannot be confined within contexts of literalism, by which is meant a neutral approach to solving the problem of political violence.

Chomsky on the other hand has stressed the limits of the doctrinal system in which definitions of "terrorism" and "terrorist" are restricted to a certain class of criminal acts and actors.93 Nevertheless, the focal point of this discussion has been the fact that terrorist violence is ultimately defined or characterized, for purposes of legal prohibition, within a highly politicized atmosphere. In particular, legal definitions of terrorism which encourage a government, the media, or other special interest group, to employ the rhetoric of danger and fear in order to intrude in the private lives of citizens in an unwarranted manner do nothing more than normalize societal expectations of, and tolerance to, increasing levels of social violence. 
The question whether to meet behind the potted plant in cyberspace thus needs refining. Despite the sheer nudity of the power relations through which official perspectives on terrorism have been contextualized historically, the more contemporary dilemma of how to (ad)dress the "terrorist" during an electronic rendez-vous clearly exposes the less edifying end(s) of democracy.

* J.D. (Eordham), LL.M., Ph.D. (University of Nottingham). The writer wishes to thank Dr. S.R. Giles for his helpful comments on earlier drafts of this article, and for introducing to her a couple of the sources which inspired and informed this effort.

1. P. Webster and I. Brodie, "G7 vow to pursue terrorists," The Times, 27 June 1996, 14.

2 . "World leaders approve call from President Clinton for a new international alliance," The Times, 28 June 1996, 1. See also the Declaration on Measures to Eliminate International Terrorism, G.A. Res. 49/60, Annex, U.N. G.A.O.R., 49th Sess., Supp. No. 49, Vol. 1, 303, U.N. Doc. A/49/49 (1995).

3 T. Rhodes, "U.S. seeks backing for plan to beat terrorism," The Times, 30 July 1996, 1.

4 B. MacIntyre, "Anti-terror war stepped up despite sanctions split," The Times, 31 July 1996, 10.

5 Id. (statement of the French foreign minister). 
6 See infra, note 40, and accompanying text. Kleff notes that "it has become de-rigueur to state at the beginning of most articles and books about terrorism that it is a concept over which people have agreed to disagree." R. Kleff, "Terrorism: The Trinity Perspective," in H.H. Han (ed.), Terrorism and Political Violence: Limits and ' Possibilities of Legal Control (New York: Oceana Publications, 1993), 13. Murphy notes that "109 different definitions of the term were advanced between 1936 and 1981, and more have appeared since." J.F. Murphy, "The Need for International Co-operation in Combating Terrorism," Terrorism: An International Journal, 1988 (13), 381 .

7 Lauterpacht defines "security" as "a system of obligations to enforce by common international action the existing limitations upon the right to go to war." $\mathrm{H}$. Lauterpacht (ed.), Oppenheim's International Law, Vol. II (London: Longmans, 7th ed. 1952), 93 n. 1. See, e.g., Lt. Col. (U.S.) R.J. Erickson, Legitimate Use of Military Force against State-Sponsored International Terrorism (Maxwell Air Force Base, Ala.: Air University Press, 1989). 8 For purposes of brevity, so-called economic terrorism will not be dealt with in other than the indicated political context.

9 See R.A. Friedlander, "The Origins of International Terrorism: A Micro Legal-Historical Perspective," Israeli Yearbook of Human Rights, 1976 (6), 49, 52; R. Kleff, supra, note $6,15-17$. 
10 Nevertheless, murder and violence as methods to effect change were common to the ancient world. R.A. Friedlander, id. $51-2$.

11 Id., $52-3$, where it is also noted that John Milton defined "tyrannicide" (the killing of a tyrant), as "not only lawful, but also laudable" (citations omitted). Cf.' E. Marks, "Diplomacy and Terrorism: Conflicting Systems," in Terrorism and Political Violence, supra, note 6, 41, 55

- 6, who characterizes this development as treason transformed into "being political."

12 See W.M. Hannay, "The Legislative Approach to the Political Offense Exception," in M.C. Bassiouni (ed.), Legal Responses to International Terrorism - U.S. Procedural Aspects (Dordrecht: Nijhoff, 1988), 115, $116 \mathrm{n}$. 3.

13 Under this exception, the sanctuary state does not view politically motivated acts of violence as crimes. See, e.g., H.H. Almond, Jr., "The Legal Regulation of International Terrorism," in Terrorism and Political Violence, supra, note 6, 199, 205, 208.

14 R.A. Friedlander, supra, note 9, 53. Thus, the seeds were sown for confusion this century between acts of insurrection, rebellion, or political protest, and the idea of terror-violence.

15 Id., 56 - 7. See also J. Dinse and S. Johnson, "Ideologies of Revolutionary Terrorism: Some Enduring and Emerging Themes," in Terrorism and Political Violence, supra, note 6,61 . 
16 R.A. Friedlander, id., 58; R. Kleff, supra, note 6, 16.

17 See C.H. Pyle, "The Political offense Exception," in Legal Responses to International Terrorism, supra, note 12, 181 - 2 n. 5; W.M. Hannay, supra, note 12, 116 n. 3. 18 Editor's notes, Hudson, International Legislation, 7', No. 499,862 .

19 Editorial Comment, Kuhn, "International Co-operation in the Suppression of Crime," American Journal of International Law, 1934 (28), 541. See also Editorial Comment, Hudson, "The Proposed International Criminal Court," American Journal of International Law, 1938 (32), 549 .

20 For example, Article $3(\mathrm{e})$ of the Convention on Extradition, signed at Montevideo, 26 December 1933. See Editor's Notes, supra, note 18 .

21 Editorial Comment, Kuhn, supra, note 19, 544. 22 Id. 543.

23 Editorial Comment, Hudson, supra, note 19, 551 (citations omitted).

24 Reprinted in Hudson, International Legislation, 7, No. 499, 862; League of Nations Official Journa1, 62, January 1938, 23. Article 26(1)(2) of the Terrorist Convention provides for entry into force ninety days after the deposit of three ratifications or accessions. 25 The convention is silent as to the purpose of the fear thus generated. 
26 A Convention for the Creation of an International Criminal Court, reprinted in Hudson, 7, No. 500, 878, supra, note 24, was opened for signature on the same day as the Terrorism Convention. Its entry into force was contingent upon that of the Terrorism Convention. Jurisdiction was optional.

27 Terrorism Convention Article 8. Article 9 permits the non-extradition of nationals.

28 While too numerous to list separately, the major terrorist conventions and other agreements are provided in O.Y. Elagab, International Law Documents Relating to Terrorism (London: Cavendish, 1995), many of which are discussed further in H.H. Almond, Jr., "The Legal Regulation of International Terrorism," in Terrorism and Political Violence, supra, note 6, 199, 206 - 10; J.F. Murphy, supra, note 6; J.F. Murphy, "The Future of Multilateralism and Efforts to Combat International Terrorism,"Columbia Journal of Transnational Law, 1986 (25), 35 .

29 See, e.g., R.J. Kuerbitz, "The Bombing of Harrods: Norms against Civilian Targeting," in W.M. Reisman and A.R. Willard (eds), International Incidents (Princeton, N.J.: Princeton University Press, 1988), 238; A. Cassesse, Violence and Law in the Modern Age (Cambridge: Polity Press, 1986); M.C. Bassiouni, "Criminological Policy," in A.E. Evans and J.F. Murphy (eds.), Legal Aspects of International Terrorism (Lexington, Mass.: D.C. Heath and Company, 1978), 523. 
Article I(4) of Protocol 1 of 1977 to the four Geneva Conventions of 1949 extends the provisions of international humanitarian law to a restrictive category of liberation conflicts. See, e.g., H.-P. Gasser, "Prohibition of Terrorist Acts in International Humanitarian Law," International Review of the Red Cross, July-August 1986 (253), 200; R.J. Erickson, supra, note 7; V. Morris and M.C. Bourloyannis-Vrailas, "Current Developments," American Journal of International Law, 1996 (90), 491, 493 (reiteration by members of the 6 th committee at the 50 th Session of the U.N.G.A. of controversial proposals to convene an international conference to define terrorism, and to differentiate it from the struggle of peoples for national liberation).

31 See, e.g., Fourth Interim Report of the I.L.A. Committee on International Terrorism, Appendix 1, Dissenting Statement by Professor L.C. Green and Dr. J. Lador-Lederer, and $Y$. Dinstein, "Comments on the Fourth Interim Report of the I.L.A. Committee on International Terrorism (1982)," Terrorism: An International Journal, 1984, 123, and 163, respectively.

32 E.T.S. 90; in force 1978.

33 See Report of the Department of State, submitted with the President's Letters of Transmittal to the U.S. Senate, reprinted in International Legal Materials, 1985 (24), 1104.

34 These mainly concern conventional offenses within the scope of aviation and diplomatic safety, the prohibition of 
hostage-taking, and common crimes such as murder, property damage, and the possession of firearms.

35 See A.D. Sofaer, "The U.S.-U.K. Supplementary Extradition Treaty," Terrorism: An International Journal, 1986 (8), 327, 336 ("with respect to violent crimes, the political offense exception has no place in extradition ' treaties between stable democracies").

36 For example, those concerning the safety of civil aviation. See also, J.J. Lambert, Terrorism and Hostages in International Law - A Commentary on the Hostages Convention 1979 (Cambridge: Grotius, 1990). 37 The text of the Draft Code that emerged on first reading proved controversial, and may be found at Yearbook of the International Law Commission, 1991 (2), 37, U.N. Doc. A/CN.4/SER.A./1991/Add.1. The U.K. has since questioned the need to continue work on the draft code given parallel work on a draft statute for an International Criminal Court. V. Morris and M.-C. Bourloyannis-Vrailas, supra, note 30,494 . The jurisdiction of the draft International Criminal Court is not linked to the draft Code. See Report of the Ad Hoc Committee on the Establishment of an International Criminal Court, UN GAOR, 50th Sess., Supp. No. 22, UN Doc. A/50/22 (1995); M.C. Bassiouni, A Draft International Criminal Code and Draft Statute for an International Criminal Tribunal (Dordrecht: Nijhoff, 1987). Cf. supra, note 26. 38 Dissent can be expressed through political agitation or labour disputes, for instance, and Devlin refers to 
44 The principle of "dual criminality" refers to the arrangement whereby extradition should only be granted if the act the fugitive is sought for is an extraditable crime according to the law of both requesting, and requested, states. See M.C. Bassiouni and V.P. Nanda, A Treatise on International Criminal Law, Vol. II (Jurisdiction and Co-' operation) (Springfield, Ill.: Thomas, 1973), $313-4$. 45 R.A. Friedlander, supra, note 9, 54. 46 See generally A. George (ed.), Western State Terrorism (Cambridge: Polity press, 1991). For example, problems arose over the meaning of the principle of dual criminality in relations between socialist and non-socialist states, leading one socialist commentator to denounce the principle as "a test of bourgeois-capitalist conceptions." M.C. Bassiouni and V.P. Nanda, supra, note 44,313 n. 18 . 47 Supra, note 1.

48 See C.H. Pyle, supra, note 17.

49 J. Dinse and S. Johnson, supra, note 15, 65. 50 Id. .

51 See, e.g., "The Poverty of Aid," The New Internationalist, November 1996 (285); D. Bigo, "L'archipel des polices," Le Monde Diplomatique, October 1996, 9; K. Tomasevski, Development Aid and Human Rights Revisited (London: Pinter Publishers, 1993); M. Lippman, "Multinational Corporations and Human Rights," in G.W. Shepherd, Jr., and V.P. Nanda (eds.), Human Rights and Third World Development (Westport: Greenwood, 1985), 249. 
52 See, e.g., "Seduced by Technology," The New Internationalist, December 1996 (286); N. Cummings-Bruce, "Muslim killers bite the hand that trained them," The Observer, 28 May 1995, 16 (Phillipine terrorists look to their Middle East backers and mentors); infra, notes accompanying section IV.d. .

53 Supra, note 4.

54 See, e.g., S. Raffy et A. Gerlach, "Carlos et I'Armée rouge du crime," Le Nouvel Observateur, 2 - 8 Août 1990, 10 .

55 See, e.g. "Les ghettos de Belfast," Le Bouleversement du Monde, Manière de Voir, Février 1995 (25), 83; B. Robertson, "Military Intervention in Civil Disturbance in Great Britain - What is the Legal Basis?," Revue de Droit Militaire et de Droit de la Guèrre, 1990 (XXIX - 1-2), 307; H. Jackson and A. McHardy, "The Two Irelands - the Problem of the Double Minority", Minority Rights Group, 3d ed. 1984 (Report No. 2).

56 See, e.g., B. Dayanin, “The Israeli supreme Court and the Deportations of Palestinians," Stanford Journal of International Law, 1994 (30), 115; "Common Agenda for the Bilateral Peace Negotiations, initialed at Washington [September 14, 1993]," reprinted in International Legal Materials, 1993 (32), 1522; R. Shehadeh, Occupier's Law Israel and the West Bank (Washington: Institute for Palestine Studies, 2d ed. 1988). 57 See J. Meek, "Chechen rebels rejoice in freedom," The Guardian, 25 November 1996, 8. 
58 Cf. the purportedly "anti-communist" rationale of the Nato-backed West European secret paramilitary network "Gladio," and the Swiss network "P26." See R. NortonTaylor, "The Gladio file: did fear of communism throw west into the arms of terrorists?," D. Pallister, "How M16 and SAS joined in," and E. Vulliamy, "Secret agents, freemasons, fascists ... and a top-level campaign of political 'destabilisation'," The Guardian, 5 December 1990,5 .

59 Sec. 1003 of title 18 U.S.C., supra, note 42, provides civil remedies in U.S. Federal Courts for victims of international terrorism. Cf. the official 1984 United States Code definition of an act of terrorism, discussed by N. Chomsky, Pirates and Emperors (Montréal: Black Rose Books, 1991), 177, which omits the third requirement. 60 See supra, note 58.

61 R.A. Friedlander, supra, note 9, 54. Cf. E. Marks, supra, note 11 .

62 See J.G. Merquior, Foucault (London: Fontana Press, 1985), 92, who links the indicated phraseology into what Foucault terms the attributes of "carceral society." 63 See, e.g., P.M. Twomey, "Denying Terrorists the Oxygen of Publicity: Broadcasting Restrictions in the UK and the Republic of Ireland", paper delivered at the W.G. Hart Legal Workshop 1994 Understanding Human Rights (London: I.A.L.S.), 5 July 1994. Chomsky terms this "the totalitarian discipline deemed appropriate within the 
(anti-terrorist) propaganda system." N. Chomsky, supra, note 59,86 .

64 See M.C. Bassiouni, supra, note 29, 530; Y. Alexander, "Introduction," in Y. Alexander (ed.), International Terrorism (New York: Praeger, 1976), xi, xiv. 65 See, e.g., Report of the I.L.A.'s 62 nd Conference (Seoul): Legal Problems of Extradition in Relation to Terrorist Offences, Draft Articles on Extradition in Relation to Terrorist offences, 1986, 559.

66 B.H. Miller, “Terrorism and Language: A Text-Based Analysis of the German Case," Terrorism: An International Journal, 1984 (9), 373.

67 Supra, note 38.

68 Id. 220.

69 A. Giddens, The Consequences of Modernity (Cambridge: Polity Press, 1990), 54.

70 Id. 33

71 See, e.g., P. Rowe, Defence: The Legal Implications: Military Law and the Laws of War (London: Brassey's Defence, 1987), $38-68$.

72 R. Falk, "The Terrorist Foundations of Recent U.S. Foreign Policy," in Western State Terrorism, supra, note $46,102,106$.

73 See, e.g., J. Verhaegen, "Legal Obstacles to Prosecution of Breaches of Humanitarian Law," International Review of the Red Cross, November - December 1987 (261), 607 . 
74 Supra, note 69, 6. See also N. Chomsky, supra, note $59,21$.

75 Supra, note 1.

76 Supra, note 62, 94. See also T. Friedman, "Turning swords into beef-burgers," The Guardian, 19 December 1996 , 17 ("no two countries that both have a McDonald's have ever fought a war against each other").

77 Supra, note 69,57 - 8. See also G. Pitt, "Rights and Employee Rights - the Case of Free Speech," in C. Gearty and A. Tomkins (eds.), Understanding Human Rights (London: Mansel1, 1996), 380 .

78 A. Giddens, id., 59 - 60. Giddens remarks further that "... there are direct relations between military power and industrialism, one main expression of which is the industrialisation of war." Id., 60 .

79 Supra, note 39.

80 See generally Le Monde Diplomatique, Août 1996. See

also R. Kleff, supra, note 6,14 , who uses the term "authentic terrorism" in order to contrast the inherent political nature of terrorism with pure criminal activity. 81 See, e.g., E. Galeano, "Guèrre aux Pauvres," Le Monde Diplomatique, id., 6 ("(1)e néolibéralisme réduit les droits des citoyens à de simples faveurs du pouvoir"). 82 See supra, note $69,29-36$.

83 S. Sloan, "State-Organized Terrorism: The Privatization of Public Violence," in Terrorism and Political Violence, supra, note 6, 129, 140. 
84 See, e.g., M. Henderson, "How I became a dangerous terrorist," The Guardian, 19 December 1996, 17 (author "bugged" after terrorist suspect caught reading her book); H. Young, "Contemptible fallout of Blair's power bid," The Guardian, 28 November 1996, 25 (Labour party fails to back House of Lords opposition to Clause 89 of the draft Police Bil1); J. Wadham, "Reflections on Recent Cases in

Strasbourg: Recent and Forthcoming Legislation in the UK," paper delivered at the W.G. Hart Workshop, supra, note 63, 7 July 1994.

85 Supra, note $83,129,134$. Cf. A. Gewirth, Human Rights: Essays on Justification and Applications (London: The University of Chicago Press Ltd., 1982), 63. 86 sloan takes note of information systems such as disposable computer banks and data bases. S. Sloan, id., 141. See, e.g., N.J. Sales, "Pynchon's coming home," The Guardian Friday Review, 6 December 1996, 2 (open-access online data service combines telephone and credit card numbers to reveal author's "secret" address in New York). Cf. D. Gow and R. Norton-Taylor, "Surfing superhighwaymen," The Guardian, 7 December 1996, 28 (nearly $\$ 10$ million of Citibank accounts transfered by hackers). 87 See also B. Thompson, "Digital Footprints" ("(m)aking the Internet easier to use also compromises privacy"), and P. Wainewright, "Tales from beyond the encrypt," The Guardian Online, 21 November 1996, 4 and 6, respectively. 88 See N. Chomsky, supra, note 59, 175. 89 Supra, note 5. 
90 Supra, note 30 , and see E. Chadwick, SelfDetermination, Terrorism, and the International Humanitarian Law of Armed Conflict (The Hague: Nijhoff, 1996); J.T. Burchael, "Framing a Moral Response to Terrorism," in C.W. Kegley, Jr. (ed.), International Terrorism (New York: St. Martin's Press, 1990), 213 (terrorism raises "new questions about all the old forms of war").

91 N. Chomsky, supra, note 59, 194.

92 Supra, notes 7 and 79 . This presumably extends to "internal security" arrangements.

93 N. Chomsky, supra, note $59,89$. 